\title{
In-situ coal seam and overburden permeability characterization combining downhole flow meter and temperature logs.
}

\author{
Julia Busse ${ }^{* *}$ Alexander Scheuermann ${ }^{1}$, Detlef Bringemeier ${ }^{1,2}$, \\ Alex Hossack ${ }^{3}$, Ling $\mathrm{Li}^{4}$ \\ ${ }^{I}$ Centre of Geotechnical Engineering, School of Civil Engineering, University of Queensland, St. Lucia, \\ Queensland, Australia; \\ ${ }^{2}$ Golder Associates Pty Ltd, Milton, Queensland, Australia; \\ ${ }^{3}$ RioTinto Coal Australia, Brisbane, Queensland, Australia; \\ ${ }^{4}$ National Centre for Groundwater Research and Training, School of Civil Engineering, University of \\ Queensland, Australia; \\ *Correspondance: j.busse@uq.edu.au
}

Received: $10^{\text {th }}$ October, 2015

Accepted: $10^{\text {th }}$ March, 2016

\begin{abstract}
The planning and design of any coal mine development requires among others a thorough investigation of the geological, geotechnical and hydrogeological subsurface conditions. As part of a coal mine exploration program we conducted heat pulse vertical flow meter testing. The flow data were combined with absolute and differential temperature logging data to gain information about the hydraulic characteristics of two different coal seams and their over- and interburden. For the strata that were localised based on geophysical logging data including density, gamma ray and resistivity hydraulic properties were quantified. We demonstrate that the temperature log response complements the flow meter log response. A coupling of both methods is therefore recommended to get an insight into the hydraulic conditions in a coal seam and its overburden.
\end{abstract}

Key words: coal seam detection, permeability, geophysical logging, exploration, methodology

\section{Introduction}

The ongoing interest in coal and interburden permeability data required for mine water and gas management needs led to an abundance of studies that focus on fluid flow in fractured coal measure rocks. A sound understanding of coal seam and overburden hydraulic conductivity is required to assess gas drainability, inrush risks, groundwater dewatering requirements and impacts on groundwater conditions.

Groundwater and gas flow in a rock mass frequently occurs along a few dominant flow channels along cleats, fissures and faults (defects). It depends on three-dimensional geometrical structural parameters like aperture, defect length and interconnectivity of the flow paths (Pyrak-Nolte et al., 1988) which in turn can change with orientation and magnitude of the stress field (Barton et al., 1995), sedimentation of fine materials and mineralisation along the flow channels (Nick, Conway, \& Fowler, 1995).

In this case study we show the advantages of coupling heat-pulse flow meter and temperature log data to detect in- and outflow zones along a borehole profile. A change in flow direction or volume, and temperature variations often occur at fracture intersections. The identification of fracture zones in seams and overburdens help to manage the mine operation. Groundwater and gas flow is likely to occur along fractures. A thorough 
investigation of the field is therefore beneficial to the practitioner.

\section{Permeability Testing of Coal Measures}

Various methods are used at coal mine sites for obtaining sub-surface data and specifically permeability estimates. Geophysical methods are used to characterise and delineate. Caliper logs present the borehole diameter $[\mathrm{cm}]$ and absolute and relative temperature $\operatorname{logs}\left[{ }^{\circ} \mathrm{C}\right]$ are used in the determination of in- and outflow zones. Pressure logs [bar], Natural gamma ray emissions [API], Resistivity [Ohm meter], Density [grams/cc], Sonic logs $[\mathrm{m} / \mathrm{s}$ ] give information about lithological features. Furthermore video logs and acoustic televiewer are in use to image borehole walls (Kirsch, 2006). Classical field methods to determine insitu permeability are pumping tests and slugtests. They are solved using analytical solutions, like the Thiem or Theis equation. Methods are implemented as single bore hydraulic testing as well as multiple bore interference testing (Price, 2009). In this study we are discussing borehole flow meter measurements and temperature data.

\section{Borehole Flow Meter Testing}

Flow meter measurements have been widely used to quantify flow along borehole profiles and to draw conclusions about the underlying hydraulic characteristics of aquifers. A review of flow meter techniques is given by MonierWilliams (2009). A range of downhole flow meters have been developed based on different principles. These are for instance impeller flow meter, heat pulse flow meter and electromagnetical flow meter (Molz et al, 1994). Dilution logging captures a flow based on conductivity measurements (Pitrak et al., 2007).

Heat pulse flow meter data deliver information on the fluid flow along the borehole and allows further quantification of in- and outflows, as well as transmissivities of the rock formations and geological structures intersected by the borehole. Using this instrument the vertical borehole flow is measured by collecting in- or outflow related data along the undisturbed borehole profile intersected by these zones. Heat pulse flow measurements have been used since the mid-eighties (Hess, 1986; Paillet et al., 1987). They are based on the travelling time of a heat pulse generated by a wire grid and transported by the moving bore fluid to thermistors placed above and below the grid. Based on the heat signal flow velocities and volumes are quantified. The highly sensitive heat pulse flow meter HFP 2293 (Mount Sopris Instrument Company) used in this study captures flow rates as small as $0.113 \mathrm{l} / \mathrm{min}$. Field measurements are carried out twice: under ambient, that is undisturbed, and stressed conditions. Stressed conditions are created either by pumping or injecting water out or into the borehole (Paillet, 1998), respectively. Plots of the results give an insight into the flow conditions along the borehole. Negative values represent downward flow. Positive values account for upward flow. Where the vertical flow changes abruptly, in- or outflow zones are concluded. A mass balance over all in- and outflow is carried out. Depending on its part on the total flow, a percentage of transmissivity for each in- or outflow zone can be estimated.

The flow in a borehole is driven by two parameters: transmissivity of the rock and head difference between the borehole and the far field aquifer, which feeds the fracture. Using an inverse modelling approach, transmissivities and far field heads for each conductive zone are calculated (Paillet, 1998). In order to solve the borehole flow equation for a certain transmissivity, borehole vertical flow values for two different head values are needed. These are obtained by field testing under ambient and stressed conditions. In an iterative process the total transmissivity of the rock profile intersected by the borehole and the head for each fracture that fits the given values are approached. 


\section{Borehole Temperature Logging}

Due to the comparably effortless measuring of temperature differences along a borehole profile, temperature data recently found an increasing use in the detection of fracture flow (Pehme et al. 2007). In coal exploration campaigns temperature logging is a costefficient geophysical standard method. Temperature data are a by-product that are needed to correct measurement data obtained with other geophysical probes, like resistivity or sonic logs.

Temperature logs represent the temperature of the fluid column in a borehole as a function of depth. Differential temperature logs depict the rate of change relative to the depth and therefore can indicate the location of areas that produce or accept water (Keys, 1971). The logs have been used to find the origin of a flow and connections between boreholes or between structures that are intersected by boreholes (Ge, 1998). Under conditions as found in the field, a qualitative interpretation of the data is feasible. If tests can be conducted at controlled conditions, for example in a large scale lab mode, temperature logs may also be analysed quantitatively (Anderson, 2005).

The main uncertainty of the temperature measurement is the time necessary for thermal adjustment of the borehole fluid after termination of the drilling activity. The temperature field around the borehole is expected to be disturbed and might not represent the undisturbed temperature conditions of the rock. In the literature different dissipation times for disturbances are reported. Haeberli \& Funk (1991) observed thermal adjustment within $24 \mathrm{~h}$ after disturbance from mechanical core drilling and snow filling to less than the measurement error of one-tenth of a degree. Stulc (1995) showed that the thermal equilibrium is reached after 184 days but the relative distributions are the same over time.

Geothermal heat can be seen as a natural tracer of ground water flow. The natural geothermal gradient depends on the heat flux, thermal conductivity of the rock and radioactive heat sources. The global average is $25^{\circ}$ Celsius per 1000 meter (m) depth (Fridleifsson, I.B., et al, 2008) with local variations. Boucher and Dominguez (2013) experimentally determined the temperature gradient at the Hail Creek mine. Based on data taken between the upper ground and $450 \mathrm{~m}$ depth the geothermal gradient is $20^{\circ}$ Celsius per $1000 \mathrm{~m}$.

The geothermal gradient is typically linear. Deviations from this trend hint at the in- or outflow of water with different temperatures. Thus, as shown by Pehme (2007), the shape of temperature profiles serve as an indication of conductive layers. Negative and positive temperature anomalies can deliver a qualitative estimation of the borehole flow. Where no gradual increase of temperature with depth occurs, an inflow in an upper zone is assumed. The relatively cooler groundwater streaming down the borehole represents the temperature present at the depth it entered the borehole. In contrast, a temperature profile with warmer temperatures than expected according to the geothermal gradient is interpreted as an inflow in a deeper zone in the borehole that is moving upwards inside the borehole. Small deviations along the profile hint at an influence of smallscale fractures with inflow of water from either warmer or cooler origins (Ge, 1998). The assessment of temperature data might allow for several different interpretations and lead to contradictory conclusions. Therefore Chatelier et al. (2011) recommend a verification of the outcomes of temperature log analysis with flow meter logs.

Desorption of gas from a coal seam is an endothermic process (Zhang et al., 2011), that is in theory borehole temperature cools down, when drilling of borehole induces degassing. The influence of this phenomenon is open to further research. The available literature focuses on the effects of temperature on gas desorption. For example temperatures are kept constant during gas desorption tests for the 
measurement of total gas content (Lama \& Bodziony, 1998).

\section{Case Study}

We analysed heat pulse flow meter and temperature log data. The data presented in this paper has been collected at the Hail Creek Mine in Central Queensland, Australia (Fig.1), which is currently subject to an extensive exploration program. Heat pulse flow meter data have been gained in several field campaigns in 2013. Rio Tinto Coal Australia provided the borehole temperature log data.

\section{Field Site}

The Hail Creek Mine is an open pit coal mine located $120 \mathrm{~km}$ south west of Mackay on the east coast of Queensland and operated by Rio Tinto Coal Australia. They produce up to eight million tonnes of hard coking coal annually at the Hail Creek coal deposit. The coal formed in the Permian is part of the Bowen Basin with an extent of $600 \mathrm{~km}$ by $250 \mathrm{~km}$. Coal is extracted from two seams at Hail Creek Mine, the Elphinstone Seam, with an average thickness of 6.4 metres (m) and the Hynds Seam, averaging $8.3 \mathrm{~m}$ in thickness. The seams are divided by an interburden of mudstone, silt- and sandstones that increases in thickness from $25 \mathrm{~m}$ up to 94 $m$ in a northward direction (Clarke, 2007) .

The coal seams outcrop on both sides of the Hail Creek syncline (Fig.2) which makes opencut mining feasible. The distance between the eastern and western limbs of the relatively shallow open syncline fold structure reach a maximum of about $7 \mathrm{~km}$. The syncline has a length of approximately $32 \mathrm{~km}$ with a maximum depth of the seams of approximately $300 \mathrm{~m}$ for the Elphinstone seam and $450 \mathrm{~m}$ for the Hynds seam at its axis. Coal seams on the western limb of the syncline dip at approximately $4^{\circ}$ to $8^{\circ}$, whilst the dip on the eastern limb is steeper with an average of $18^{\circ}$ (Stadter \& Hair, 2014).

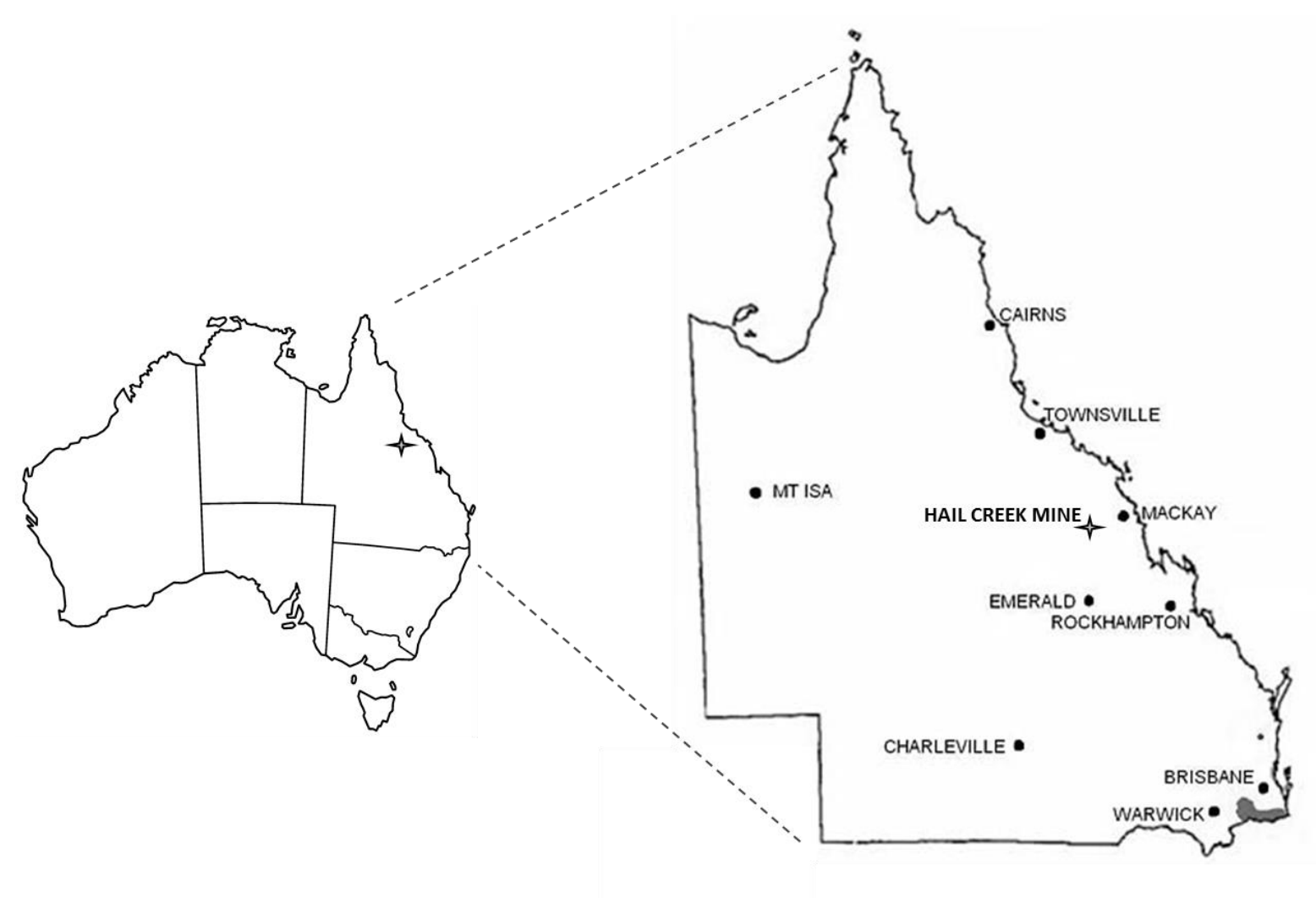

Fig.1. Location of Hail Creek Mine in Central Queensland, Australia (www.ehp.qld.gov.au) 
The near surface Rewan Group of Triassic age is characterised by the absence of coal. In the ongoing open pit mining operation, coal is extracted from the shallower parts at the northwestern flank of the Rangal Coal Measures. They are underlain by the Fort Cooper Coal Measures which consist of lithic sandstone, conglomerate, mudstone, carbonaceous shale, coal, tuff and tuffaceous mudstone. The subsequent Moranbah Coal Measures include labile sandstone, siltstone, mudstone, coal and conglomerate.

The syncline is built of sedimentary strata of Permian and Triassic age and covered by a relatively thin layer of quaternary alluvials, consisting of clay, sandy clay and paleochannels of sand and gravel. It trends south-southeast, its axis central to the Hail Creek mine field. Following the syncline and influenced by the drainage due to the pit operation, the main flow direction of shallow groundwater and surface water is southeast (Golder Associates Pty Ltd, 2013). Fig. 3 shows the groundwater levels above Australian Height Datum and indicated flow directions measured in coal exploration boreholes in 1980 and 2009. In comparison the latter data show a drawdown of the groundwater table of approximately $5 \mathrm{~m}$ to $15 \mathrm{~m}$ in proximity to the open-cut operations (King, 2009).
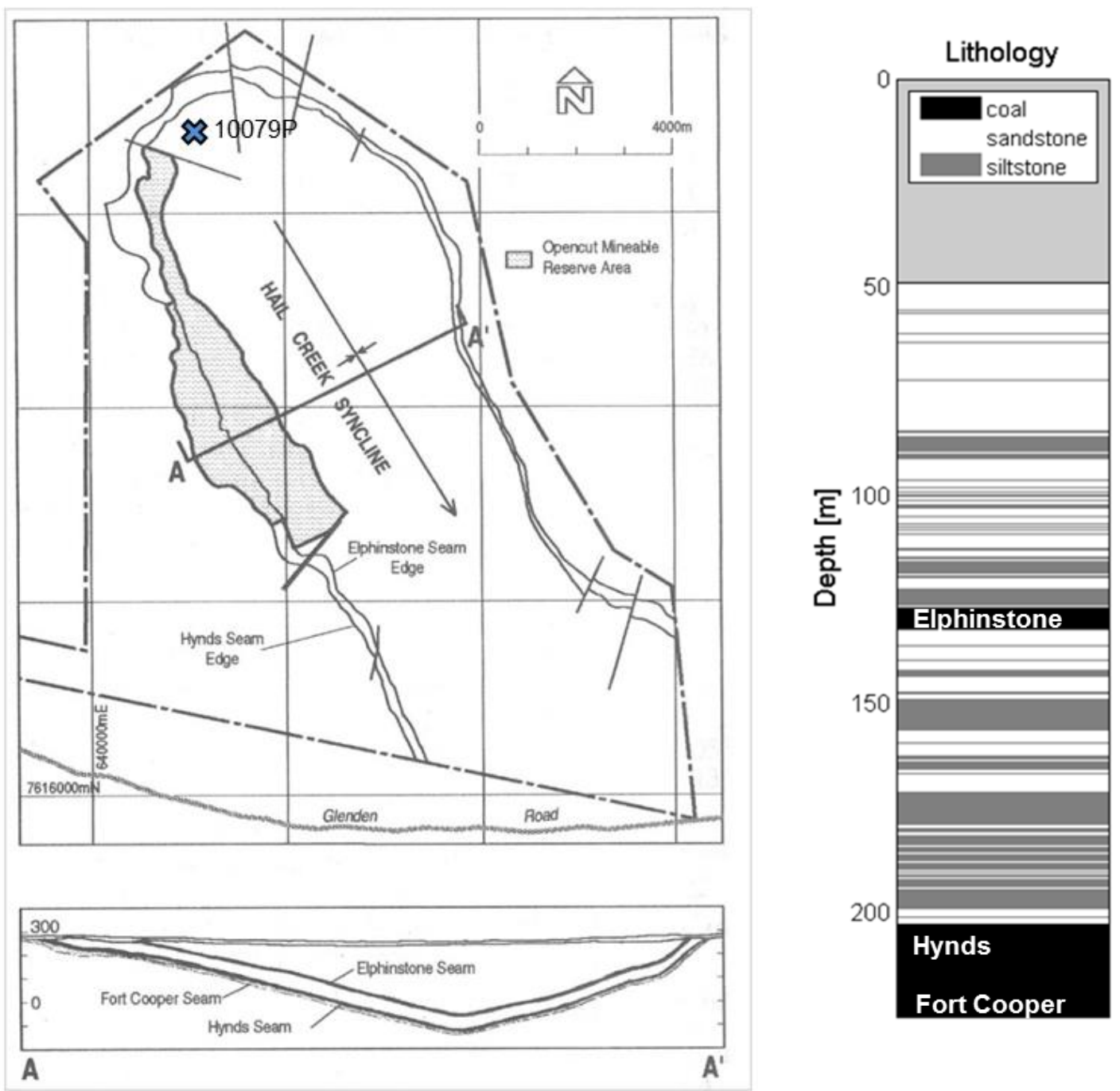

Fig.2. Hail Creek syncline with position of borehole 10079P in relation to the open pit (Rio Tinto, 2010) and lithology of borehole 10079P 
A summary of former hydrogeological investigations done in the area has been completed by Stadter \& Hair (2014) and includes data which span four decades (i.a. Golder Associates Pty Ltd, 2013). Hydraulic conductivities decrease with depth from 0.017 $\mathrm{m} /$ day in the overburden to a minimum of 1.1 * $10^{-5} \mathrm{~m} /$ day in the Fort Cooper Seam. The spatial distribution of borehole data is irregular, with few data points in the centre of the area, where the seams are deepest, and comparably many in the west margin of the syncline where open cut mining is taking place.

Areas of increased permeability occur locally in jointed and faulted sandstone with hydraulic conductivities of up to $89 \mathrm{~m} /$ day mainly following the northwest to southeast orientated axis (Stadter \& Hair, 2014). Major normal faults are found in the resource area east of the syncline. Less significant faulting and low angle thrusting occur in the far north and south east of the area (Golder Associates Pty Ltd, 2013). Although these small scale faults do not cause significant dislocation of strata they appear to locally increase the permeability resulting in higher groundwater yields (King, 2009).

The investigation discussed in this paper was conducted at borehole $10079 \mathrm{Pm}$. Its position relative to the open pit is depicted in Figs 2 and 3. A stratigraphic column shows the lithology of borehole 10079P (Fig.2).

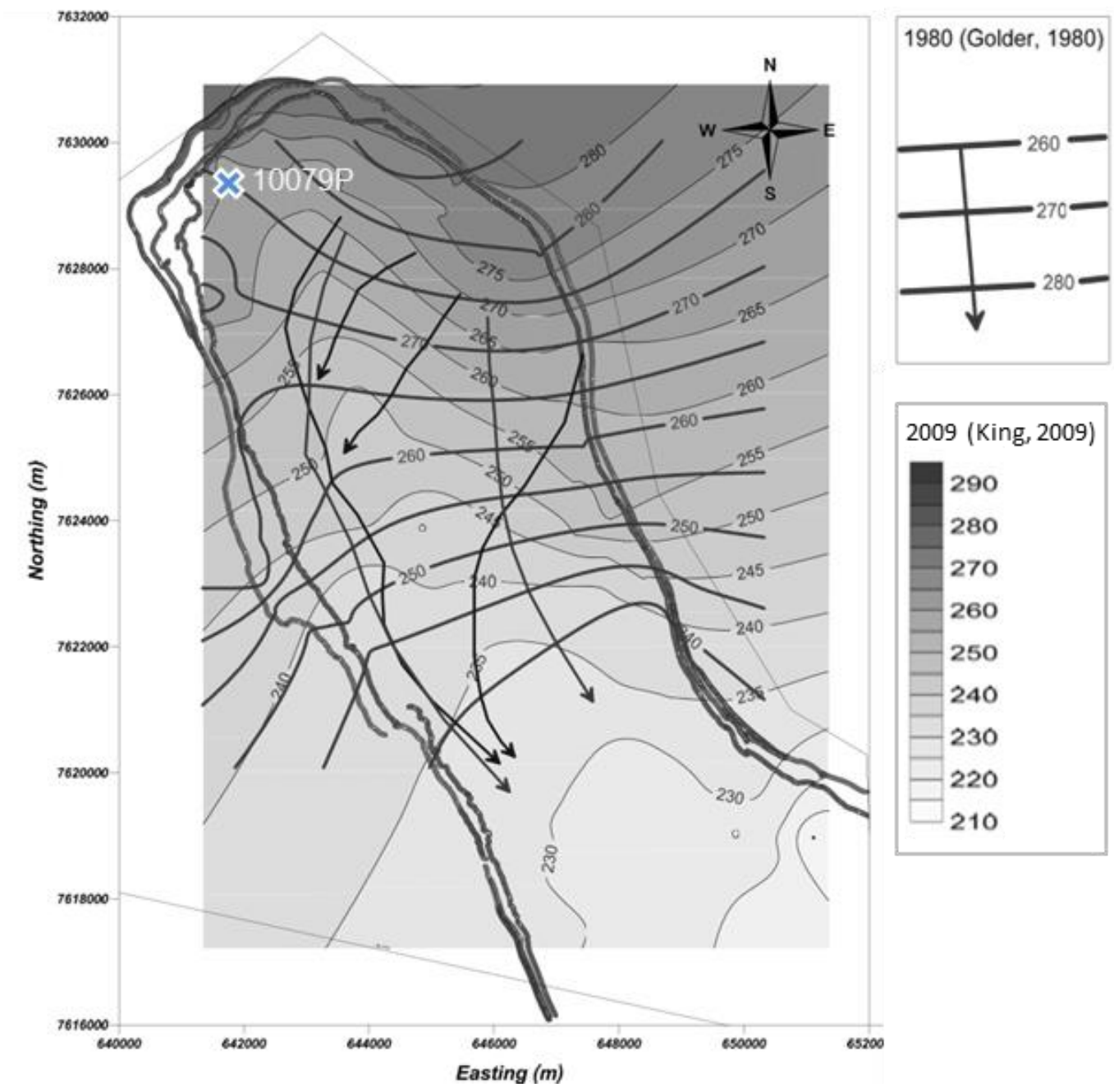

Fig.3. Groundwater levels in $\mathrm{m}$ above sea level and indicated flow directions (taken from King, 2009, based on data from Golder, 1980) 


\section{Site Investigation}

Borehole 10079P which is subject to discussion in this paper has been drilled as part of the 2013 exploration program at the Hail Creek Mine extension site. Borehole 10079P is located at $642643.45 \mathrm{~m}$ East and 7629241.20 North, with an elevation of $279.95 \mathrm{~m}$ AHD. It has a diameter of $125 \mathrm{~mm}$, a total depth of $225 \mathrm{~m}$ and was drilled using rotary wash boring with water as a drilling fluid. The bore is fitted with a protective PVC casing from the surface to $49 \mathrm{~m}$ depth. Temperature data have been collected during a field survey in July 2013, at the same day drilling of the borehole was completed. We conducted the flow meter logging four days later.

Groundwater level at time of logging was $5.71 \mathrm{~m}$ below ground level. Borehole 10079P intersected the Elphinstone and Hynds seam between 125.97 and $130.59 \mathrm{~m}$, and between $203.28 \mathrm{~m}$ and $211.11 \mathrm{~m}$, respectively. The Fort Cooper seam was intersected just below that from a depth of $211.11 \mathrm{~m}$ to the total depth of the borehole (Fig.2).

We collected flow data at the borehole $10079 \mathrm{P}$ using a heat pulse flow meter under ambient and injection conditions. Relative transmissivities were calculated as described earlier by Busse et al (2013). The location of the borehole is depicted in Figs 2 and 3. The plot of the flow under both conditions (Fig.4) allows an insight into the upwards or downwards direction of groundwater flow along the profile. It serves for detecting in- and outflow zones, which are marked in the flow profiles. Measurement spacing varies between $0.5 \mathrm{~m}$ in the coal seams and $10 \mathrm{~m}$ in areas where no flow was detected.
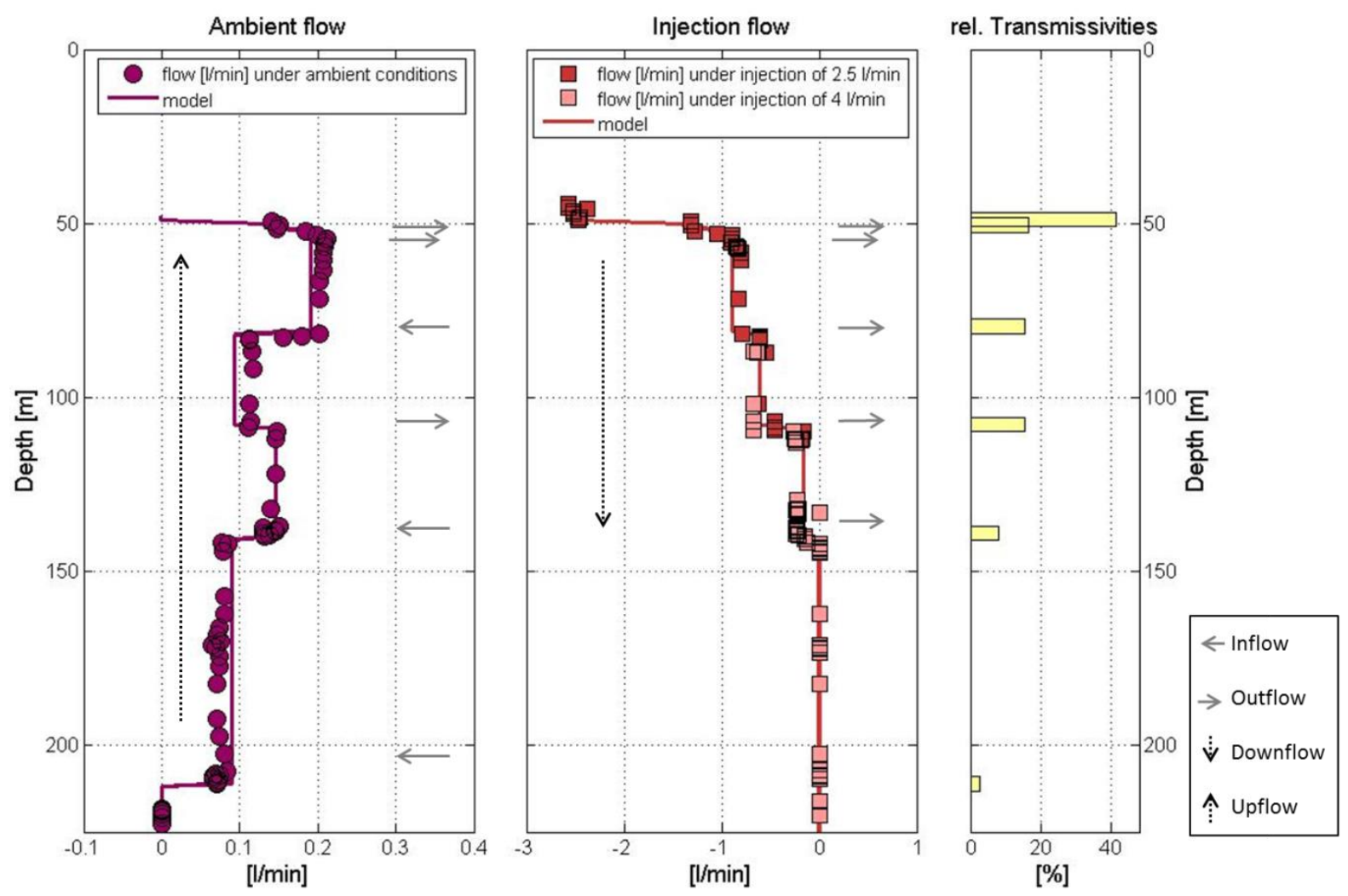

Fig.4. In- and outflow along borehole profile 
We did the injection testing using two different flow rates. An injection of $2.5 \mathrm{l} / \mathrm{min}$ was applied at the upper half of the borehole. For the flow measurements recorded at greater depth 4 1/min was fed into the borehole. The increase of the flow was necessary to compensate water losses into the formation. Augmenting the injection rate ensures that the vertical flow in the lower part of the borehole is sufficient to be detected by the flow meter. The data for the latter case $(4 \mathrm{l} / \mathrm{min})$ have been normalized (Busse et. al, 2013).

Downhole temperature measurements were taken at $0.1 \mathrm{~m}$ sampling intervals. The differential temperature is the product of the raw data of the temperature measurements with a 21-point differential filter applied to it (Savitzky \& Golay, 1964).

\section{Flow Meter Testing Results}

The flow profile delivers quantitative information about the hydraulic conductive zones and six transmissive zones could be differentiated. The six zones vary in thickness from less than $0.5 \mathrm{~m}$ to $3.23 \mathrm{~m}$. For the purpose of simplification the discussion uses the depth in metres of the middle of each zone (Fig.4).

Under ambient conditions an up-flow all along the borehole up to the zone at $49.14 \mathrm{~m}$ was detected, with an inflow of $0.071 / \mathrm{min}$ at $211.44 \mathrm{~m}$ depth and further inflow of $0.07 \mathrm{1} / \mathrm{min}$ at $140.36 \mathrm{~m}$. An outflow of $0.03 \mathrm{l} / \mathrm{min}$ at 108.87 $\mathrm{m}$ leads to a slightly smaller up-flow of 0.11 $1 / \mathrm{min}$, which increases again to $0.19 \mathrm{l} / \mathrm{min}$ after an inflow of $0.08 \mathrm{l} / \mathrm{min}$ at $81.25 \mathrm{~m}$. Just below the end of the casing we detected two zones where water leaves the borehole into the formation: $0.05 \mathrm{l} / \mathrm{min}$ at $51.91 \mathrm{~m}$ and $0.14 \mathrm{l} / \mathrm{min}$ at $49.41 \mathrm{~m}$.

A second measurement under stressed conditions revealed a similar zoning. The vertical borehole flow is directed downward, which is depicted by negative values in the flow profile (Fig.4). Along the borehole profile from top to bottom the injected water streams out into the rock formation. Therefore the down flow along the profile gradually decreases with depth. The seepage into the formation at 140.36 $\mathrm{m}$ depth was $0.14 \mathrm{l} / \mathrm{min}$. At $108.87 \mathrm{~m}$ depth an outflow of $0.41 \mathrm{l} / \mathrm{min}$ was measured and at $81.25 \mathrm{~m}$ depth another $0.31 \mathrm{l} / \mathrm{min}$ exit the borehole. The next two zones at $50.4 \mathrm{~m}$ and $48.89 \mathrm{~m}$ account for an outflow of $0.461 / \mathrm{min}$ and $1.18 \mathrm{l} / \mathrm{min}$, respectively. No flow at the lowermost zone is detected under injection conditions.

The flow profile data is summarized in Tab.1 below.

Tab.1. Flow in borehole 10079P

\begin{tabular}{lcccc|ccc|ccc}
\hline \multicolumn{2}{ll}{ Zone } & \multicolumn{3}{l}{} & \multicolumn{3}{|c|}{ Ambient Test Conditions } & \multicolumn{3}{c}{ Injection Test } \\
\hline $\mathrm{nr}$ & $\begin{array}{c}\text { from } \\
{[\mathrm{m}]}\end{array}$ & to & thickness & middle & above & below & flow & above & below & flow \\
& {$[\mathrm{m}]$} & {$[\mathrm{m}]$} & {$[\mathrm{m}]$} & {$[1 / \mathrm{min}]$} & {$[1 / \mathrm{min}]$} & {$[1 / \mathrm{min}]$} & {$[1 / \mathrm{min}]$} & {$[1 / \mathrm{min}]$} & {$[1 / \mathrm{min}]$} \\
\hline 6 & 48.89 & 49.39 & 0.5 & 49.14 & 0.00 & 0.14 & -0.14 & -2.50 & -1.32 & -1.18 \\
5 & 50.4 & 53.42 & 3.02 & 51.91 & 0.14 & 0.19 & -0.05 & -1.32 & -0.86 & -0.46 \\
4 & 79.63 & 82.86 & 3.23 & 81.25 & 0.19 & 0.11 & 0.08 & -0.86 & -0.55 & -0.31 \\
3 & 107.86 & 109.87 & 2.01 & 108.87 & 0.11 & 0.14 & -0.03 & -0.55 & -0.14 & -0.41 \\
2 & 139.1 & 141.62 & 2.52 & 140.36 & 0.14 & 0.07 & 0.07 & -0.14 & 0.00 & -0.14 \\
1 & 211.18 & 211.69 & 0.51 & 211.44 & 0.07 & 0.00 & 0.07 & 0.00 & 0.00 & 0.00 \\
\hline
\end{tabular}


Adding up the conductive zones, a total hydraulic conductivity of $1.26 \mathrm{~m} /$ day was found for the overburden. No transmissive feature was detected where the Elphinstone coal seam is located. The interburden between the Elphinstone and the Hynds seam has a hydraulic conductivity of $0.04 \mathrm{~m} /$ day. For the Hynds seam $0.078 \mathrm{~m} /$ day was measured. The Fort Cooper seam has not been detected to be contributing to the total borehole transmissivity. The fact that no transmissive features were identified at the Elphinstone and Fort Cooper horizons is unusual as former investigations showed that the coal seams are the primary aquifers.

The results of the heat pulse flow meter testing are shown in Tab.2.
The flow data are compared to other hydraulic conductivity results determined from more traditional hydrogeological data collection techniques at Hail Creek Mine. The results by Golder Associates Pty Ltd (2013) and Stadter \& Hair (2014) are depicted in Fig.5. These data include results from pumping tests, falling head tests, constant head tests, heat pulse vertical flow meter tests, falling head packer tests, and constant rate injection packer tests that are dating back until 1973.

For overburden and interburden, the current heat pulse flow meter data plot slightly above the range of values measured before. For the Hynds seam the heat pulse flow data lie inside the ranges depicted in Fig.5.

Tab.2. Results of heat pulse flow meter testing for borehole 10079P

\begin{tabular}{|c|c|c|c|c|c|}
\hline \multicolumn{2}{|c|}{$\begin{array}{c}\text { Depth tested } \\
{[\mathrm{m} \text { below ground }]}\end{array}$} & \multirow{2}{*}{$\begin{array}{l}\text { Test length } \\
{[\mathrm{m}]}\end{array}$} & \multirow{2}{*}{$\begin{array}{l}\text { Transmissivity } \\
{\left[\mathrm{m}^{2} / \text { day }\right]}\end{array}$} & \multirow{2}{*}{$\begin{array}{l}\text { Hydraulic conductivity } \\
\qquad[\mathrm{m} / \text { day }]\end{array}$} & \multirow{2}{*}{$\begin{array}{c}\text { Intrinsic } \\
\text { permeability } \\
{[\mathrm{mD}]}\end{array}$} \\
\hline Top & Bottom & & & & \\
\hline 48.89 & 49.39 & 0.5 & 0.52 & 1.040 & 1111.04 \\
\hline 50.4 & 53.42 & 3.02 & 0.2 & 0.066 & 70.75 \\
\hline 79.63 & 82.86 & 3.23 & 0.19 & 0.059 & 62.84 \\
\hline 107.86 & 109.87 & 2.01 & 0.19 & 0.095 & 100.98 \\
\hline 139.1 & 141.62 & 2.52 & 0.1 & 0.040 & 42.39 \\
\hline 211.18 & 211.69 & 0.51 & 0.04 & 0.078 & 83.79 \\
\hline
\end{tabular}

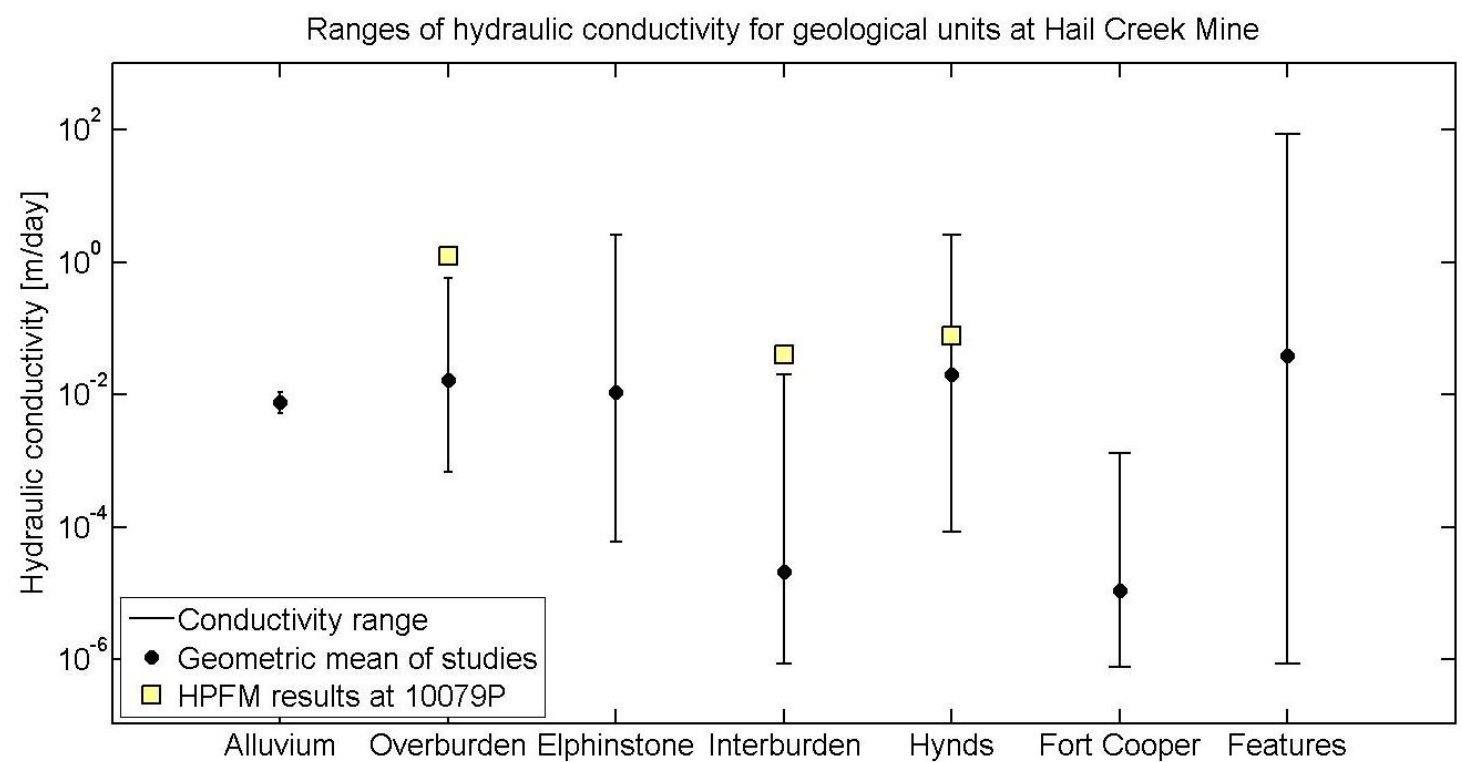

Fig.5. Hydraulic conductivities measured by heat pulse flow meter compared to results of former studies (based on Stadter \& Hair (2014) 


\section{Temperature Data}

Absolute and differential temperature has been collected as part of the geophysical logging campaign in July 2013.

Fig. 6 shows the temperature profiles of six boreholes at the Hail Creek site. A regression of these data sets leads to an average geothermal gradient of $23.17^{\circ} \mathrm{C}$ per $1000 \mathrm{~m}$ at the site. This value is slightly higher than the $20^{\circ} \mathrm{C}$ per 1000 $\mathrm{m}$ found in an earlier study. The absolute temperature profile of the borehole 10079P is highlighted; it follows an average gradient of $21.3^{\circ} \mathrm{C}$ per $1000 \mathrm{~m}$. The gradient of borehole $10079 \mathrm{P}$ is therefore smaller than the average in the area, which is distorted by the influence of one borehole with a comparably steep gradient. This borehole is about $100 \mathrm{~m}$ deeper than the others.
The absolute and differential temperatures are depicted in Fig.7. We concluded the position of in- and outflow zones based on the temperature distribution relative to the geothermal gradient. They are marked in the plot.

Anomalies in the downhole temperature become more evident in the plot of differential temperature. Where deviations in the differential temperature records occur, an in- or outflow is assumed. For borehole 10079P anomalies occur at five positions. They are used for a detailed description of the flow along the borehole. The results are discussed in the following from the top to the end of bore. A flow zone is defined by a deviation in the differential temperature curve. It is delimited by the nearest local minima below and above that peak.
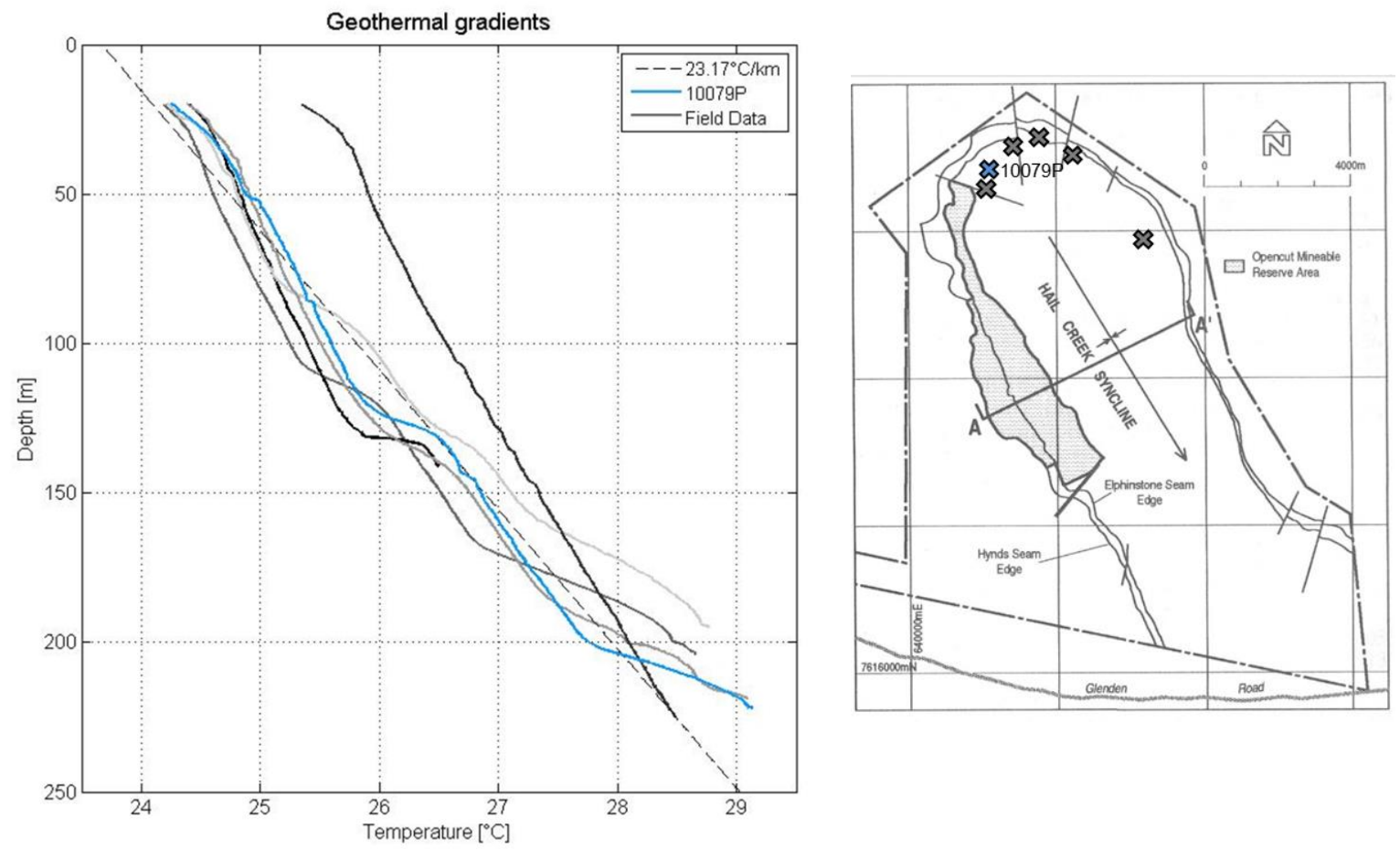

Fig.6. Temperature profiles of boreholes logged at Hail Creek Mine and their relative location at the site 

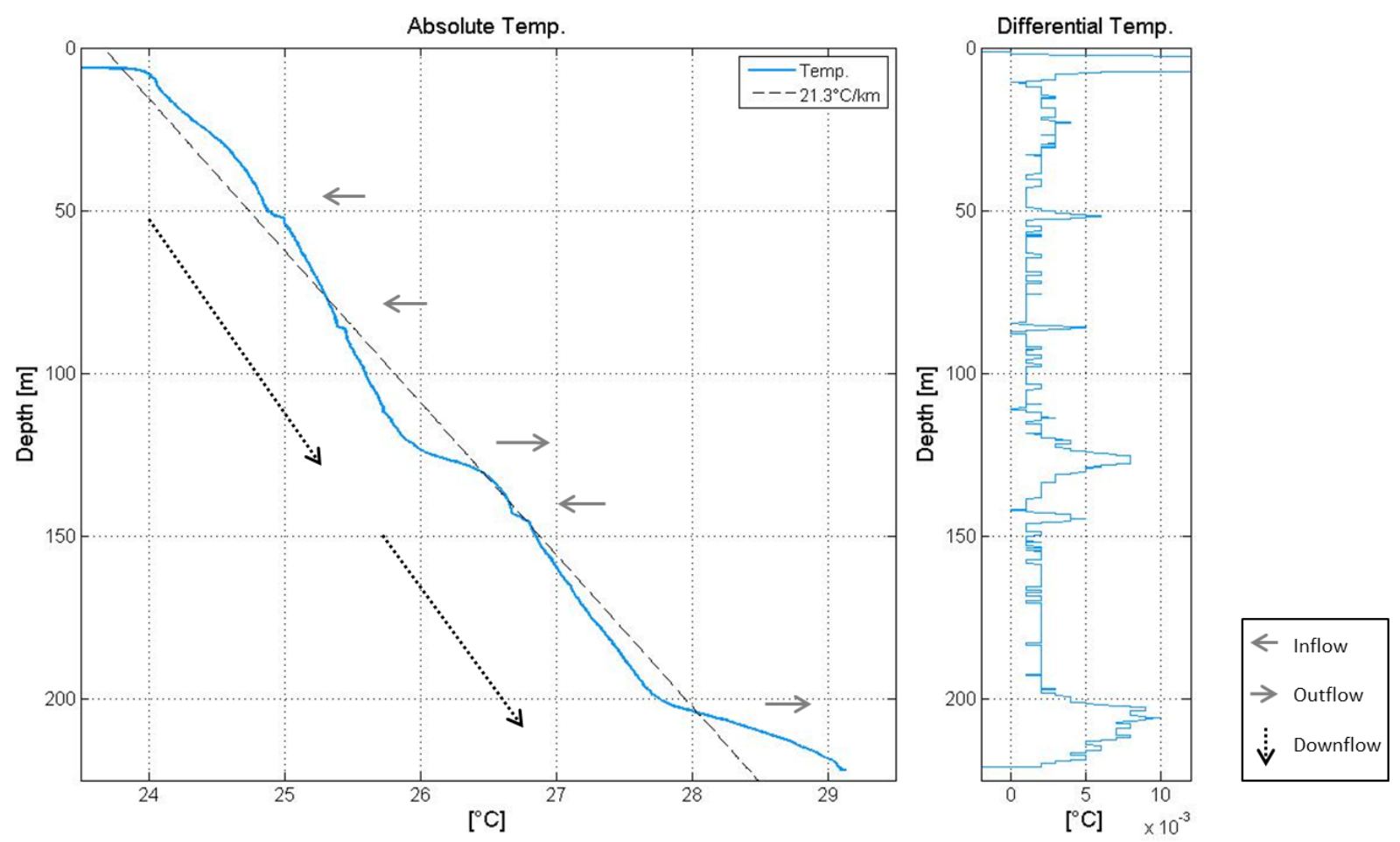

Fig.7. Temperature profile of borehole 10079P

The deviation at $51.75 \mathrm{~m}$ indicates groundwater inflow. Another inflow is noted at $86 \mathrm{~m}$. Up to a depth of $125.8 \mathrm{~m}$ we observed borehole fluid temperatures that are lower than the geothermal gradient theoretically would account for. At this depth an outflow of the cooler water causes the temperature curve to bend towards the geothermal gradient line. This is interpreted as an outflow along the Elphinstone seam.

Another inflow is assumed at $144.3 \mathrm{~m}$ depth. The downstream of cooler water results in a steepening of the temperature curve. The flow is directed downwards along the borehole profile until a zone which has its peak at 202.6 $m$ depth. From here the gradient gradually drops from over a $20 \mathrm{~m}$ interval. The negative temperature anomaly finds a smooth transition towards the temperature curve that is expected according to the geothermal gradient. This accounts for the Hynds coal seam.

Deviations in the temperature gradients are observed in each coal seam. This is due to the generally higher permeability of coal compared to the over- and underlying rock.

The flow zones detected by the temperature method are shown in Tab.3.

Tab.3. Results of temperature testing for borehole 10079P

\begin{tabular}{ccccc|cc}
\hline Zone & & & & & \multicolumn{2}{c}{ Flow condition observed } \\
\cline { 1 - 3 } $\mathrm{nr}$ & from $[\mathrm{m}]$ & to $[\mathrm{m}]$ & thickness $[\mathrm{m}]$ & peak $[\mathrm{m}]$ & Inflow & Outflow \\
\hline 5 & 50.8 & 52.9 & 2.1 & 51.75 & $\mathrm{x}$ & \\
4 & 84.8 & 87.2 & 2.4 & 86 & $\mathrm{x}$ & \\
3 & 121.7 & 141.8 & 20.1 & 125.8 & & $\mathrm{x}$ \\
2 & 141.9 & 146.3 & 4.4 & 144.3 & $\mathrm{x}$ & \\
1 & 197.3 & 219.9 & 22.6 & 202.6 & & $\mathrm{x}$ \\
\hline
\end{tabular}




\section{Discussion}

Temperature data and heat pulse flow data provide insight into the transmissivity of the rock formation intersected by the borehole. However, the application of the two techniques in the same borehole and the comparison of the results allow further insight into the location of transmissive structures and the flow regimes.

Results of both methods collected from borehole 10079P drilled at Hail Creek mine are given in Tab.4. They are marked depending on the instrument the flow zone was detected with. Zones that only occurred in the by the flow meter measurements are marked in red. Zones that were found using the temperature method are marked in blue. Those that have influenced both measurements are marked with grey. The offsets of these results have been calculated. The off-set between both logs along the borehole profile is not consistent.

The results of the study are also plotted in Fig.8. In- and outflow zones detected by both methods are marked with a grey continuous line in the plot. A blue dashed line is drawn where deviations are found in the temperature plot only. In- and outflow zones that can only be concluded from the flow meter measurements appear with a red dashed line. For the following discussion the depths are prefixed with an $\mathrm{F}$ for the flow meter method and a $\mathrm{T}$ for the temperature method.

Tab.4. Overview of flow zones detected by the both methods

\begin{tabular}{|c|c|c|c|c|c|c|c|c|c|}
\hline & \multicolumn{5}{|c|}{$\begin{array}{l}\text { Flow zones detected by flow meter only (red), } \\
\text { temperature meter only (blue) and both methods (grey) }\end{array}$} & \multicolumn{4}{|c|}{ Offset } \\
\hline & Method & $\begin{array}{l}\text { from } \\
{[\mathrm{m}]}\end{array}$ & $\begin{array}{c}\text { to } \\
{[\mathrm{m}]}\end{array}$ & $\begin{array}{l}\text { thickness } \\
\text { [m] }\end{array}$ & $\begin{array}{l}\text { middle/ peak } \\
{[\mathrm{m}]}\end{array}$ & $\begin{array}{l}\text { from } \\
{[\mathrm{m}]}\end{array}$ & $\begin{array}{c}\text { to } \\
{[\mathrm{m}]}\end{array}$ & $\begin{array}{l}\text { thickness } \\
{[\mathrm{m}]}\end{array}$ & $\begin{array}{l}\text { middle/ } \\
\text { peak }[\mathrm{m}]\end{array}$ \\
\hline$\square$ & Flow meter & 48.89 & 49.39 & 0.5 & 49.14 & & & & \\
\hline$\Pi$ & Flow meter & 50.4 & 53.42 & 3.02 & 51.91 & & & & \\
\hline L & Temperature & 50.8 & 52.9 & 2.1 & 51.75 & & & -0.92 & -0.10 \\
\hline$\Gamma$ & Flow meter & 79.63 & 82.86 & 3.23 & 81.25 & & & & \\
\hline L & Temperature & 84.8 & 87.2 & 2.4 & 86 & 4.11 & 4.34 & -0.83 & 4.15 \\
\hline$\square$ & Flow meter & 107.86 & 109.87 & 2.01 & 108.87 & & & & \\
\hline$\square$ & Temperature & 121.7 & 141.8 & 20.1 & 125.8 & & & & \\
\hline 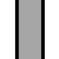 & Flow meter & 139.1 & 141.62 & 2.52 & 140.36 & & & & \\
\hline L & Temperature & 141.9 & 146.3 & 4.4 & 144.3 & 2.0 & 4.00 & 1.00 & 3.74 \\
\hline$\square$ & Temperature & 197.3 & 219.9 & 22.6 & 202.6 & & & & \\
\hline$\square$ & Flow meter & 211.18 & 211.69 & 0.51 & 211.44 & & & & \\
\hline
\end{tabular}




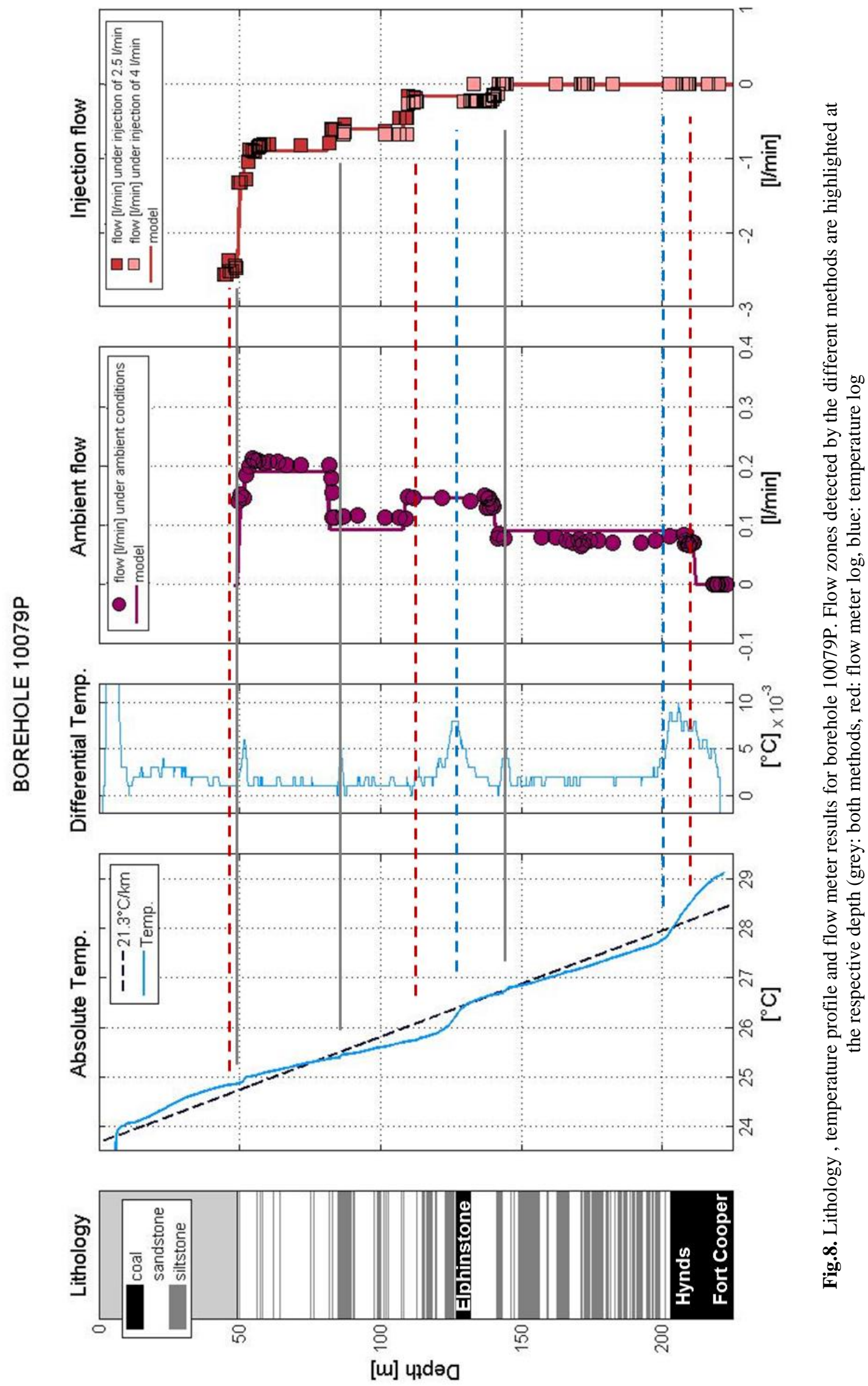


Only the flow meter data deliver results that quantify the flow. The results depicted in Fig.8 reveal that there are in- and outflow zones that are not detected by the flow meter method but become obvious when assessing the temperature profile along the borehole. This is the case at T-126.5 $\mathrm{m}$ where a strong deviation in the differential temperature log indicates an outflow.

Furthermore, the temperature data shows a deviation at T-205.85 m. In close proximity, a conductive layer is also indicated by the flow meter method (F-211.44 m). Both measurements indicate the Hynds seam as a flow zone. While a low flow is only visible in the ambient flow data and not under injection conditions, it is very pronounced in the differential temperature plot and also in the absolute temperature plot. There are two more zones where both methods deliver results. Analogies are found at F-81.25 m and T-86 m, as well as F-140.36 m and T-144.35 m. The offset between the depths of zones that are inferred from both methods are somewhat constant around $5 \mathrm{~m}$. This reveals the potential of combining the heat pulse flow meter and temperature measurements for a useful depth correction.

On the absolute temperature plot three of the zone boundaries are associated with an abrupt increase of temperature. Elsewhere changes are more gradual. Overall, the temperature data show a distinct change in temperature caused by outflows at the locations of the coal seams. This observation meets the expectation of generally higher transmissivities for the seams. It is noted that temperature deviations along the borehole might have been caused by the disturbance of the ambient temperature field due to the injection of relatively cooler water during drilling. This serves as an additional confirmation of the presence of a coal seam. The coals are more transmissive; during drilling, they will take up larger volumes of cooler water which will then produce lower temperature zones in the temperature log.

In- and outflow zones that inferred from the flow data, but not indicated by the temperature data might hint at a flow that is too small to modify the water column temperature inside the borehole. These results could also be caused by water entering the borehole which is originating from the same depth as the borehole fluid and therefore has the same temperature.

The outflow zone indicated by the flow meter measurements at F-108.87 m depth does not have a counterpart in the temperature data. Just below the casing a stepwise change of flow over a short section is detected (F-49.41 m and $\mathrm{F}-51.91 \mathrm{~m}$ ). This pattern remains invisible in the temperature data, where only $\mathrm{T}-51.75 \mathrm{~m}$ is detected.

Noteworthy is the inconsistency in the overall flow directions. While the temperature profile hints at down-flow along the borehole, up-flow was detected using the heat pulse flow meter. This up-flow, which continues from the Hynds coal seam at $211.44 \mathrm{~m}$ up to $49.41 \mathrm{~m}$ bottom, contradicts the expectation of downflow with the borehole being located at a distance of $1300 \mathrm{~m}$ to an open pit which should cause drainage. These findings also do not fit the overall flow direction due to local pressure heads as depicted in Fig.3.

The occurrence of this up-wards directed flow of the water in the borehole could be caused by the degassing of the coal seams. Gas bubbles forming due to the pressure release after drilling of the borehole move towards the groundwater surface and drive the borehole fluid upwards. The measured values therefore do not represent the hydrogeological conditions but are superimposed by the effect of degassing. This may be because the flow data was measured only four days after completion of drilling due to time restraints of the field campaign. For future studies repeated borehole flow measurements over time are advised to further investigate the influence of degassing. The possibly enhanced up-flow driven by 
degassing is of interest, as well as the effect of endothermic degassing on the temperature of the borehole fluid.

\section{Conclusion}

This case study presents an in-situ characterisation of the hydrogeological parameters of coal seams using flow meter and temperature logs. The combination of both data sets delivers a different picture as the interpretation of each data set alone.

Coupling the results of both methods, inand outflows into and from the borehole can be detected. These observations are directly related to transmissive coal seams. We expected to identify and correct possible inaccuracy in the depth of inferred in- and outflow zones by using both data sets, but found inconsistent off-sets along the borehole profile.

It is concluded that each of the methods has its shortcoming. While we generally have little doubt about the quality of the HPFM $\log$, uncertainty was introduced by degassing of the coal that caused an up-flow along the borehole. It is recommended to include a sufficient waiting period when drilling in coal measure rocks to eliminate the influence of degassing on the borehole flow. While in the presented case the influence of degassing on the borehole flow was strong four days after drilling, local variations of gas contents and permeability have to be considered.

Anomalies in borehole fluid temperature data can be interpreted as in- and outflow of groundwater into or from the borehole and therefore serve as evidence for transmissive rock formations and single fractures or fracture zones intersecting the borehole. The temperature data deliver continuous results every $0.1 \mathrm{~m}$. It has to be noted that the ambient groundwater temperature field around a borehole is likely to be disturbed when drilling with fluids. Therefore, this method may be prone to inaccuracies and does not allow a quantitative, but only a qualitative interpretation of the data.

For both logging methods the measurement interval, length and depth are subjective choices which may vary between a few centimetres up to several tens of metres, depending on the time and cost constraints the investigation faces. To eliminate possible depth errors, the existing application could be modified to measure temperature and flow meter data simultaneously.

Coupling heat pulse flow meter data with absolute and differential temperature data enables to achieve comprehensive information on the hydraulic conditions. While this case study was done as part of an exploration of a coal field, the application of the method is not limited to the use in coal mining. The knowledge of hydraulic parameters in fractured rocks is also crucial to water supply and questions of contamination in regions with hard rock geology.

\section{Acknowledgments}

The work with the heat pulse flow meter has been supported ongoing by the expertise of Dr. Fred Paillet. The study is funded by an ACARP grant and the ARC Linkage Project "Multiscale, two-phase flow in complex coal seam systems", and is kindly supported by Rio Tinto Coal Australia and its staff at Hail Creek Mine. The contributions of an anonymous reviewer are kindly acknowledged.

\section{References}

Anderson M.P. (2005) Heat as a Ground Water Tracer. Ground Water, 43(6), 951-968. doi:10.1111/j.1745-6584.2005.00052.x

Barton C.A., Zoback M.D., Moos D. (1995) Fluid flow along potentially active faults in crystalline rock. Geology. doi:10.1130/00917613(1995)023<0683:FFAPAF $>2.3 . C O$

Busse J., Scheuermann A., Galindo-Torres, S.D., Bringmeier D., Li L., (2013) In-situ 
and laboratory measurements of coal matrix and cleat permeability, Conference proceedings UNSAT 2014: Unsaturated soils: Research and applications, Sydney, Australia, 02.-04. July 2014

Boucher, C., \& Dominguez, J. (2013) Stage 1 Gas Reservoir Characterisation. GeoGAS for Rio Tinto Coal Australia.

Chatelier, M., Ruelleu, S., Bour, O., Porel, G. \& Delay, F. (2011) Combined fluid temperature and flow logging for the characterization of hydraulic structure in a fractured karst aquifer. Journal of Hydrology, 400, 377-386.

Clarke, G. (2007) Documentation of Significant Geological Features evident within Rio Tinto's Hail Creek Coal Mine. In: MINE, M. T. S. H. C. C. (ed.).

Fridleifsson, I.B., et al. (2008) The possible role and contribution of geothermal energy to the mitigation of climate change. IPCC scoping meeting on renewable energy sources, proceedings, Luebeck, Germany. Vol. 20. No. 25.

Ge, S. (1998) Estimation of groundwater velocity in localized fracture zones from well temperature profiles. Journal of Volcanology and Geothermal Research 84.1: 93-101.

Golder Associates Pty Ltd (1980) Hail Creek Coal Project, Geotechnical Investigations for Open Cut Mining. Report prepared for Hail Creek Coal Pty Limited. Project No: 29058

Golder Associates Pty Ltd (2013) Factual Report on Hydrogeological Investigations at the Hail Creek Mine Site. In: MATTERN, J. (ed.). Rio Tinto Coal Australia Pty Ltd.

Haeberli, W., \& Funk, W. (1991). Borehole temperatures at the Colle Gnifetti coredrilling site (Monte Rosa, Swiss Alps), (125), 37-46.

Hess, A. E. (1986) Identifying hydraulically conductive fractures with a slow-velocity borehole flowmeter. Canadian Geotechnical Journal 23.1: 69-78.

Keys, W.S., Maccary, L. (1971) Application of borehole geophysics to water-resources investigations. US Government Printing Office.

King, A, Hair, I. (2009) Hydrogeological assessment of Hail Creek coal mine, Prepared for RioTinto Coal Australia.

Kirsch, R. (2006). Groundwater geophysics (Vol. 493). Springer.

Lama, R. D., \& Bodziony, J. (1998) Management of outburst in underground coal mines. International Journal of Coal Geology, 35(1-4), 83-115. doi:10.1016/S0166-5162(97)00037-2

Molz, F. J., Boman, G. K., Young, S. C. \& Waldrop, W. R. (1994) Borehole flowmeters: field application and data analysis. Journal of Hydrology, 163, 347371.

Monier-Williams, M. E., Davis, R.K., Paillet, F.L., Turpening, R.M, Sol, S.J.Y., Schneider, G.W. (2009) Review of Borehole Based Geophysical Site Evaluation Tools and Techniques. Nuclear Waste Management Organization, Toronto, Ontario, Canada.

Nick, K., Conway, M. W., \& Fowler, K. S. (1995). The Relation of Diagenetic Clays and Sulfates to the Treatment of Coalbed Methane Reservoirs. In SPE Annual Technical Conference and Exhibition. Society of Petroleum Engineers.

Paillet, F. L., Hess, A. E., Cheng, C. H. \& Hardin, E. (1987) Characterization of Fracture Permeability with High-Resolution Vertical Flow Measurements During Borehole Pumping. Ground Water, 25, 2840.

Paillet, F. L. (1998) Flow modeling and permeability estimation using borehole flow $\operatorname{logs}$ in heterogeneous fractured formations. Water Resources Research, 34, 997-1010. 
Pehme, P., Greenhouse, J. \& Parker, B. (2007)

The Active Line Source Temperature Logging Technique and its Application in Fractured Rock Hydrogeology. Journal of Environmental and Engineering Geophysics, 12, 307-322.

Pitrak, M., Mares, S. \& Kobr, M. (2007) A simple borehole dilution technique in measuring horizontal ground water flow. Ground Water, 45, 89-92.

Pyrak-Nolte, L. J., Cook, N. G. W., \& Nolte, D. D. (1988) Fluid percolation through single fractures. Geophysical Research Letters.

Rio Tinto (2010). Hail Creek Coal Mine. Deposit Geology. [Power Point slides].

Savitzky, A., \& Golay, M. (1964) Smoothing and differentiation of data by simplified least squares procedures. Analytical Chemistry. Retrieved from http://pubs.acs.org/doi/abs/10.1021/ac6021 $4 \mathrm{a} 047$

Stadter, M. \& Hair, I. (2014) Report on Groundwater Flow Modelling for the Hail Creek Underground Project Feasibility Study (p. 48). Hail Creek Coal Mine via Nebo, North Queensland.

Stulc, P. (1995) Return to thermal equilibrium of an intermittently drilled hole: theory and experiment. Tectonophysics, 241(1-2), 3545. doi:10.1016/0040-1951(94)00183-A

Zhang, L., Aziz, N., Ren, T., \& Wang, Z. (2011) Influence of Temperature on the Gas Content of Coal and Sorption Modelling. In 11th Underground Coal Operators Conference (Ed.), (pp. 269-276). University of Wollongong \& the Australasian Institute of Mining and Metallurgy. 